\title{
The Cause and Consequences of Unemployment: A Case Study in Debre Birhan Town, Ethiopia
}

\author{
Terefe Admaw \\ Lecturer, Department of Economics, College of Business and Economics, \\ Assosa University, Assosa, Ethiopia
}

\begin{abstract}
The general objective of the study is to assess the cause and consequences of unemployment in Debre Birhan town. The specific objectives of the study is to examine the current condition of unemployment in Debre Birhan town, to examine the cause and consequence of urban unemployment in the town and to put some possible measures to tackle the problem in the town. The study used simple random sampling technique and selected 100 respondents randomly from the unemployed population in the Debre Birhan town. Thus, depending on the study the main cause of unemployment in the town are lack of job opportunity, lack of initial capital to start work, lack of skill and experience, rural urban migration and smoking cigarette and using shisha. While the consequences are dependency, bad ethics, lack of peace and security and crime. Because of the seriousness of the problem measures like giving opportunity to self-employed activities, expanding private institutions to create job opportunities, establishing non-governmental and governmental institution should be taken to reduce unemployment in the town.
\end{abstract}

DOI: $10.7176 / \mathrm{DCS} / 11-2-04$

Publication date: February $28^{\text {th }} 2021$

\section{Introduction}

Unemployment is one of the major problems faced by the most of people in the world. Not only in the present but also in the past, unemployment became the most serious problem. Nowadays unemployment increased both in underdeveloped and developed countries due to the increase in population. Youth unemployment has a serious effect not only on the living standards of the people (negative effects on the psychology, socio-economic and physical well-being) but also on the socio-economic status of a nation (Fitsum, 2014).

During the first Growth and Transformation Plan of Ethiopia (GTP) from (2011-2015) more emphasis was given to youth development such as empowering women and youth to ensure their social, economic and political participation than directly focusing on issue of unemployment (Marta, 2012). In the two successive development plans the government has induced employment interventions for youth through integrating TVET to the need SMEs development and subsidizing the employment creation projects in integrated housing, construction and infrastructure development programs (MoFED, 2010). However, despite these efforts in Ethiopia youth unemployment remains widespread. Particularly urban educated youth unemployment rate is increasing year to year (Marta, 2012).

The industrial revolutions changed the nature of working activity and introduced unemployment as a problem for society. This is because the industrial revolution was accompanied by a shift to wage labor and to a division of responsibilities. This is because the industrial revolution change the nature of production marked a significant change in the nature of the unemployment problem. First it created the possibility of cyclical unemployment, with wage set at certain level, when the economic activity cut down, workers income per hour did not fall. Instead, factories would fire some workers that are not what happened on the farm, when a slack period occurred on the farm, the income per hour of all workers fall and few were staid off. Second the industrial revolution was accompanied by a change in how families dealt with unemployment, where as in pre-industrial farm economies individuals or families took responsibilities for their own slack periods; in capitalist industrial society factory owners did not take responsibility for their workers in slack periods. Worldwide employment opportunities and other social goods for young people have been affected largely by the effects of globalization, the neoliberal economic and social reforms and labor market transformation (Jeffrey, 2010).

According to Keynesian economic theory, unemployment results from insufficient effective demand for the goods and services in an economy. Some believe that structural problems and inefficiencies in the labor market cause unemployment. Other believes that regulations like minimum wage laws imposed on the labor market lead to unemployment. The consequences of unemployment can be grave as homelessness due to failure of the unemployed individuals to repay home loans or pay house rents. On losing jobs people are forced to take up jobs that do not benefit their skills, experience and education, and qualification. The other major consequences of unemployment are anxiety in the minds of the unemployed people. Unemployed individuals become pessimistic about life and may have to face psychological problems resulting from mental stress. Unemployment hampers the economic as well as the social status of the society. Unemployment benefit serves as a strong support during the period of one's unemployment (Gupta, 2008). 
Inflation is one of the oldest causes of unemployment. A state economy faces a steep rise in price as compared to other economies of the world. This leads to failure in exports as companies are not able to compete with others due to rise in price. Low income people's savings fall and gradually companies start people, being unable to pay their dues in time, thus, the rate of unemployment increases. In addition to this, changing technology, job dissatisfaction, welfare payment, economic recession, racial discriminations are the causes of unemployment. According to Marx unemployment exists as a result of the capitalist system itself and gradually worsens. He did not believe that in the long-term capitalist economies could be managed to eliminate unemployment, nor did he think that market forces would reduce unemployment their own consensus (Tesfaye, 2015).

Unemployment is one of the major factors that affect the development of the nation. It is not the recent phenomena but has long history before the post war period. In spite of these periods the voluntary and involuntary unemployment with slightly increased from time to time. Ethiopia is one of the underdeveloped countries, which is characterized by the existence of unemployment. Urban unemployment is a serious problem in Ethiopia, because of the expansion of urban area and the migration of people from rural to urban area. According to CSA (1999), unemployment includes the economically active population who were not engaged in productive activities during most of the twelve months preceding the survey date (Kuris, 2006).

Unemployment is one of the major problems faced by the under developed countries and the developed one's that the entire world must fight against these major issues. Therefore, policies are needed to help unemployed people to develop skills and increase their access to information and credits, so that they are better to make choice among available opportunities. When we see in the case of Africa especially sub-Sahara Africa has a great problem of unemployment. This is because of increase in population and declining of the economy of these countries. These ideas tell that there is high degree of unemployment in Ethiopia which makes the society vulnerable to different kinds of problems in their life. There are also factors or causes which are responsible for the existence of unemployment.

In Debre Birhan Town unemployment is a recent phenomenon. This is because of people's migration from rural to urban part of town, and there is also urban population growth. As the town becomes urbanized the number of peoples increases and job opportunity for those people becomes less and they become unemployed. Especially nowadays urban unemployment in the town becomes the key problem. By completing this research, the researcher hopes to explore the many causes of unemployment, consequence of unemployment, a realization of the seriousness of the problem in the town and suggestion as to what can be done to alleviate these problem. Specially, this typical study raises the following questions:

- What are the major causes that made to the rise of unemployment in Debre Birhan town?

- What are the major consequences of unemployment?

- What are the best policy measures to reduce unemployment?

Thus, this study needs to explain the causes and consequence of unemployment in Debre Birhan Town.

\section{Materials and Methods}

\subsection{Data Source and analysis}

This research paper employed both primary and some sort of secondary data. Primary data were collected through questionnaire, while secondary data were collected from sources like central statistic authority (CSA), Debre Birhan town police administration office and micro and small scale enterprise office of Debre Birhan town. The data has been analyzed through descriptive method of analysis.

\subsection{Method of sampling}

The researcher used probabilistic sampling technique. Under this sampling technique, simple random sampling technique has been used to give equal chance to every unemployed individual of the population in the town. According to the survey by micro and small scale enterprise bureau at the beginning of 2020, there were 5465 unemployed individuals in the town. From those unemployed individuals 4711 were employed in this year. Currently there are 754 unemployed individuals in the town. Thus a sample of 100 respondents has been selected for this study.

\section{Results and Discussion}

In this part the study analyzed the data which is collected from both primary and secondary sources. Primary data was collected by using questionnaire. The questionnaire is prepared for 100 unemployed individuals in the town. Secondary data is collected from different sources like Central Statistics Authority (CSA), Micro and small scale enterprise office and Debre Birhan town police administration office. After the data were collected from primary and secondary data sources the researcher analyzed and interpreted the data depending on different views from the respondents and facts which is related to unemployment. 


\subsection{Demographic characteristics of the respondents}

Table 1: Age group and sex of the respondents

\begin{tabular}{|l|c|c|c|c|}
\hline \multirow{2}{*}{ Age group } & \multicolumn{2}{|c|}{ Sex } & \multicolumn{2}{c|}{ Respondents } \\
\cline { 2 - 5 } & Male & Female & Total number & Percentage \\
\hline $14-32$ & 54 & 36 & 90 & $90 \%$ \\
\hline $33-50$ & 2 & 8 & 10 & $10 \%$ \\
\hline $51-70$ & - & - & - & - \\
\hline Greater than 70 & - & - & - & - \\
\hline Total & 56 & 44 & 100 & $100 \%$ \\
\hline
\end{tabular}

Source: own survey (2020)

As we observe from the above table high rate of unemployment is registered to the age group of 14-32 and low rate of unemployment is registered at the age group of 33-50 and there are no unemployed respondents whose age is greater than 50 i.e. age group (51-70). This means $90 \%$ of unemployed individuals are the productive ones and they are under the youth group. This indicates that the youth are the productive section of the society which becomes unemployed, so that their contribution to the economy of the town is low, because they don't have any job that increases their income.

Table 2: Martial status of respondents

\begin{tabular}{|l|c|c|c|c|}
\hline \multirow{2}{*}{ Marital status } & \multicolumn{4}{c|}{ Respondents } \\
\cline { 2 - 5 } & Male & Female & Total number & Percentage \\
\hline Married & 11 & 16 & 27 & 27 \\
\hline Unmarried & 42 & 23 & 65 & 65 \\
\hline Divorced & 3 & 5 & 8 & $100 \%$ \\
\hline Total & 56 & 44 & 100 & 8 \\
\hline
\end{tabular}

Source: own survey (2020)

The marital status of both female and male affect their participation in different working activities. The above table shows that the number of unmarried unemployed is greater than that of married and divorced. The percentage share of unemployed married, unmarried and divorced individuals are $27 \%, 65 \%$ and $8 \%$ respectively. Hence, there are no more jobs in the town as they are unable to get work and they face difficulty to lead their life as well as their family.

Table 3: Educational background of respondents

\begin{tabular}{|l|c|c|c|c|}
\hline \multirow{2}{*}{ Level of Education } & \multicolumn{3}{c|}{ Respondents } \\
\cline { 2 - 5 } & Male & Female & Total number & Percentage \\
\hline Illiterate & 4 & 3 & 7 & 7 \\
\hline Completed primary school & 28 & 18 & 46 & 46 \\
\hline Completed high school & 15 & 20 & 35 & 35 \\
\hline Diploma & 3 & 4 & 7 & 7 \\
\hline Degree & 5 & - & 5 & 5 \\
\hline Master & - & - & - & - \\
\hline Total & 55 & 45 & 100 & $100 \%$ \\
\hline
\end{tabular}

Source: own survey (2020)

The above table shows the educational back ground of the respondents. Here, the problem of illiterate unemployed exists because they don't have any certificate which indicates that they have not graduated from college or university. And, this is because most of the people have not completed their education due to different reasons like they don't get support from their family and lack of initiation. The percentage share of illiterate respondents is $7 \%$. The problem of educated unemployed highly exists in primary school completed $46 \%$ followed by $35 \%$ of high school completed respondents. Educated unemployed individuals for diploma and degree accounts $7 \%$ and $5 \%$ respectively. Since most of unemployed individuals are primary and high school complete, they face difficulty to get job as they do not graduate from any institution i.e. they do not graduate from university or college. 
Table 4: Respondents living condition

\begin{tabular}{|l|c|c|c|c|}
\hline \multirow{2}{*}{ The respondents live with } & \multicolumn{3}{c|}{ Respondents } \\
\cline { 2 - 5 } & Male & Female & Total number & percentage \\
\hline With father and mother & 27 & 15 & 42 & 42 \\
\hline With mother only & 8 & 7 & 15 & 15 \\
\hline With father only & 3 & 3 & 6 & 6 \\
\hline With relatives & 7 & 17 & 24 & 24 \\
\hline With friends & 10 & 3 & 13 & 13 \\
\hline Total & 55 & 45 & 100 & $100 \%$ \\
\hline
\end{tabular}

Source: own survey (2020)

Table 4 indicates that most of unemployed individuals live with their family that is they live with their father and mother. Since they do not have any income for their living they are forced to depend on their family which accounts $42 \%$ and individuals who live with their mother only, father only, relative only and with friend accounts to $15 \%, 6 \%, 24 \%$, and $13 \%$ respectively. So, this implies that even if they have power to work but they could not get job because of lack of education, and lack of job opportunity which is not available in the town.

Table 5: Shows the respondents who had job before and do not have now

\begin{tabular}{|l|c|c|c|c|}
\hline \multirow{2}{*}{ Have you been employed before? } & \multicolumn{4}{|c|}{ Respondents } \\
\cline { 2 - 5 } & Male & Female & Total number & percentage \\
\hline Yes & 9 & 10 & 19 & 19 \\
\hline No & 46 & 35 & 81 & 81 \\
\hline Total & 55 & 45 & 100 & $100 \%$ \\
\hline
\end{tabular}

Source: own survey (2020)

The table shows that unemployed respondents who had jobbed before and who do not have been jobbed even before this time. The individuals who had job before accounts to $19 \%$ and most of the individuals around $81 \%$ do not have any job before. From these we understand that most of the respondents had no job before this time, this is because of that unemployment is not the problem of today but it is a problem in the previous time for the town.

Table 6: Shows the respondents who had job before and in what type of work they engaged.

\begin{tabular}{|l|c|c|c|c|}
\hline \multirow{2}{*}{ The type of work they engaged } & \multicolumn{3}{|c|}{ Respondents } \\
\cline { 2 - 5 } & Male & Female & Total number & percentage \\
\hline Self employed & 10 & 8 & 18 & 94.7 \\
\hline In government works & - & - & - & - \\
\hline Non-governmental works & - & 1 & 1 & 5.3 \\
\hline Total & 10 & 9 & 19 & $100 \%$ \\
\hline
\end{tabular}

Source: own survey (2020)

From the above table we can deduce that $94.7 \%$ of unemployed individuals were engaged in self- employed activities and $5.3 \%$ of unemployed individuals were engaged in non-governmental works, but he/she is not continued until now with those jobs as their job is not permanent as compared with government works. And there are no respondents from government works.

Table7: Illustrates people who had no job before and from where they get income

\begin{tabular}{|l|c|c|c|c|}
\hline \multirow{2}{*}{$\begin{array}{l}\text { From where they get the required } \\
\text { income }\end{array}$} & \multicolumn{4}{|c|}{ Respondents } \\
\cline { 2 - 5 } & Male & Female & Total respondents & Percentage \\
\hline Depending on their family & 46 & 32 & 78 & 96.3 \\
\hline Depending on their relatives & - & 3 & 3 & 3.7 \\
\hline From the money accumulated before & - & - & - & $100 \%$ \\
\hline Total & 46 & 35 & 81 & - \\
\hline
\end{tabular}

Source: own survey (2020)

The table above indicates that respondents who had no job previously and in what way they found income for their living. Here, $96.3 \%$ of unemployed respondents get income from their family and 3.7\% get income from their relatives and none of the respondents have accumulated income before. From this one conclude that since most of the individuals are unemployed they do not have any share to develop the economy of the town as well as the economy of the country. 
Table 8: Unemployed by duration of time

\begin{tabular}{|l|c|c|c|c|}
\hline For how long you become & \multicolumn{3}{|c|}{ Respondents } \\
\cline { 2 - 5 } unemployed? & Male & Female & Total respondents & Percentage \\
\hline For half year & 18 & 9 & 27 & 27 \\
\hline For one year & 12 & 15 & 37 & 37 \\
\hline For 2-5 year & 18 & 8 & 26 & 26 \\
\hline For greater than 5 year & 8 & 12 & 20 & $100 \%$ \\
\hline Total & 56 & 44 & 100 & \\
\hline
\end{tabular}

Source: own survey (2020)

The table indicates that the duration of unemployment for the respondents' and shows for how many years or for how much time the individuals become unemployed. About $27 \%$ of the individuals become unemployed for half year, $37 \%$ of the individuals for one year, 26 percent of the individual become unemployed for 2-5 years and 20 percent of the respondent do not have job for more than five year. This implies that the longer period of unemployment duration exacerbates the problem of unemployment and the shorter period of unemployment duration lowers the problem of unemployment.

\subsection{Major causes of unemployment}

The cause of unemployment is different for different countries in the world. This means that the cause of unemployment in developed country is different from that of underdeveloped country. The cause of unemployment in underdeveloped country is mostly linked with lack of education and inability of the country to create job opportunity, but in the case of developed country the cause is related to technological advancement. Nebil, et al. (2010) identified poor economic performance of the country and higher rural urban migration as a main cause for youth unemployment.

Table 9: Major causes of unemployment explained by the respondents

\begin{tabular}{|l|c|c|c|c|}
\hline \multirow{2}{*}{ Major causes } & \multicolumn{4}{|c|}{ Respondents } \\
\cline { 2 - 5 } & Male & Female & Total respondents & Percentage \\
\hline Lack of job opportunity & 22 & 16 & 38 & 38 \\
\hline Lack of education & 19 & 9 & 28 & 28 \\
\hline Migration from rural to urban & 7 & 12 & 19 & 19 \\
\hline No better working place & 8 & 7 & 15 & 15 \\
\hline Total & 56 & 44 & 100 & $100 \%$ \\
\hline
\end{tabular}

Source: own survey (2020)

From the table we observe that the majority of the individuals become unemployed because of lack of job opportunity, which account $38 \%$ and lack of education that is $28 \%$ of the total unemployed. The other that is migration from rural to urban and because of absence of better working place covers $19 \%$ and $15 \%$ respectively. Table 10: Shows respondents who says smoking cigarette and using shisha lead to unemployment

\begin{tabular}{|c|c|c|c|c|}
\hline \multirow{2}{*}{$\begin{array}{l}\text { Does smoking cigarette and using shisha lead to } \\
\text { unemployment? }\end{array}$} & \multicolumn{4}{|c|}{ Respondents } \\
\hline & Male & Female & $\begin{array}{c}\text { Total } \\
\text { respondents }\end{array}$ & Percentage \\
\hline Yes & 51 & 41 & 92 & 92 \\
\hline No & 4 & 4 & 8 & 8 \\
\hline Total & 55 & 45 & 100 & $100 \%$ \\
\hline
\end{tabular}

Source: own survey (2020)

As it is indicated in the table the number of respondents who agree with the idea that smoking cigarette and using shisha lead to unemployment $(92 \%)$ is much higher than the respondents who do not agree $(8 \%)$. This implies smoking cigarette and using shisha leads to unemployment.

\subsection{Consequences of unemployment}

Unemployment is one of the most serious problems especially for underdeveloped country like Ethiopia. Because of the existence of unemployment there are many consequences for unemployed individuals. Its consequences are lack of peace and security, bad ethics, addiction to bad practices, lack of self-respect, dependency and thefts and street dwellers. 
Table 11: Consequences of unemployment in the town

\begin{tabular}{|l|c|c|c|c|}
\hline \multirow{2}{*}{ Consequences of unemployment } & \multicolumn{4}{|c|}{ Respondents } \\
\cline { 2 - 5 } & Male & Female & Total respondents & Percentage \\
\hline Lack of peace and security & 14 & 7 & 21 & 21 \\
\hline Bad ethics and addiction & 13 & 11 & 24 & 11 \\
\hline Lack of self-respect & 7 & 4 & 11 & 44 \\
\hline Dependency & 24 & 20 & 44 & $100 \%$ \\
\hline Total & 58 & 42 & 100 & \\
\hline
\end{tabular}

Source: own survey (2020)

As explained by the respondents the main consequences of unemployment include dependency, bad ethics and addiction, lack of peace and security and lack of self-respect. So according to their responses $21 \%$ of the respondents affected by lack of peace and security, about $24 \%$ affected by bad ethics, around $11 \%$ of them says unemployment results lack of self-respect and $44 \%$ affected by dependency. This implies that the problems are not limited only affecting the individual rather it extends to disturb or affect the society as a whole.

\subsection{Effects of rural-urban migration in the town}

Table 12: Effect of rural-urban migration explained by the respondents

Effect of rural urban migration in the town

Respondents

\begin{tabular}{|l|c|c|c|c|}
\hline Increasing of urban people in the town & Male & Female & Total respondents & Percentage \\
\hline Increasing of urban unemployed in the town & 17 & 11 & 28 & 28 \\
\hline Increasing of poor people in the town & 25 & 19 & 44 & 44 \\
\hline Total & 17 & 11 & 28 & 28 \\
\hline
\end{tabular}

Source: own survey (2020)

According to the respondents response rural-urban migration has its own effect for the increase of unemployment in the town. From the total of unemployed individuals $28 \%$ of them said that the effect of rural urban migration is increasing of urban people in the town, $44 \%$ of unemployed individuals said that the effect of rural urban migration is increasing of urban unemployed in the town, and another $28 \%$ of unemployed individuals said that the effect of urban-rural migration is increasing of poor people in the town. So, from these we can deduce that rural urban migration is the cause for the existence of unemployment in the town.

3.5. Solutions to reduce unemployment in the town

Table13: Solution to reduce unemployment

\begin{tabular}{|l|c|c|c|c|}
\hline Measure that must be taken to reduce unemployment & \multicolumn{4}{|c|}{ Respondents } \\
\cline { 2 - 5 } & Male & Female & Total respondents & Percentage \\
\hline Expanding private institutions to create job opportunity & 18 & 9 & 27 & 27 \\
\hline Establishing government institutions & 9 & 2 & 11 & 11 \\
\hline Establishing non-governmental intuitions & 10 & 6 & 16 & 16 \\
\hline Give opportunity to self-employment activities & 24 & 22 & 46 & 46 \\
\hline Total & 61 & 39 & 100 & $100 \%$ \\
\hline
\end{tabular}

Source: own survey (2020)

The table above shows that the response of the respondents to reduce unemployment in the town. Around $27 \%$ of the respondents explain that expanding private institutions to create job opportunities, $11 \%$ of the respondents says that to establish government institutions, $16 \%$ of respondents says to establish nongovernmental institutions, and $46 \%$ of respondents asks seeks opportunity for self-employment activities respectively. This could be the solution by their intuition.

The researcher raises a question to the respondents about the problem of unemployment to the social and economic condition of the town. Some of the problems of unemployment to the social and economic condition of the town are the following.

$>$ The existence of unemployment makes individual to become poor and they exposed to malnutrition, because they do not get revenue (income) for their living, these in turn makes them to exposed for moral hazard (demoralization)

$>$ Unemployment lowers the country's GDP i.e. unemployed individuals do not contribute anything to increase the GDP of the county and they lack patriots for their country because of these they become a problem to the economy as they disturb the nations.

$>$ Unemployed individuals do not participate in social/living or social life because they are segregated from the society.

$>$ In addition to the above, unemployed individuals are forced to do unnecessary thing that means they make 
or participate in crime (crime expansion)

In Debre Birhan town unemployment is still the problem for both literate and illiterate individuals. In the case of educated certificate and diploma graduate are in searching of jobs but not find ones. Likely degree holders face the problem of unemployment though not worse as that of illiterate individuals.

According to the data from Debre Birhan town police administration office unemployed individuals whose age is greater than 18 exposed to crime. In the current year (2013), the numbers of unemployed individuals who participate in crime are around 67. Both female and male are participate in criminal activities. These individuals participate in different types of crime activities like:

* Stealing and theft

* Robbery (use violence for stealing)

* Use drugs and shisha or they use unnecessary drugs like shisha to steal money or other material (good) from the society.

Table 14: The type of criminal activities that unemployed individuals engaged

\begin{tabular}{|c|c|c|c|c|}
\hline \multirow[t]{2}{*}{ The type of crime they engaged } & \multicolumn{4}{|c|}{ Respondents } \\
\hline & Male & Female & $\begin{array}{c}\text { Total } \\
\text { respondents }\end{array}$ & Percentage \\
\hline Stealing and theft & 23 & 2 & 25 & 37.4 \\
\hline Robbery (using violence) & 21 & - & 21 & 31.3 \\
\hline $\begin{array}{l}\text { Use un necessary drugs and shisha to steal money or other } \\
\text { good from the society }\end{array}$ & 17 & 4 & 21 & 31.3 \\
\hline Total & 61 & 6 & 67 & 100 \\
\hline
\end{tabular}

Source: Debre Birhan Town police administration office (2020)

The table above tells us unemployed individual in the town are highly engaged in stealing theft, which accounts $37.4 \%$ from unemployed criminal. The remaining who are engaged in robbery and drug and shisha users are accounts $31.3 \%$ and $31.3 \%$ respectively from the total unemployed criminal in the town. From these one can conclude that unemployment become a serious problem to the town as it makes individuals to do criminal activities which is restricted by law. As compared to female, male are highly exposed to criminal activities i.e. the number of male who are engaged in criminal activities is higher than the number of female who were engaged in criminal activities.

\section{Conclusion and Recommendations}

\subsection{Conclusion}

Unemployment is one of the most serious problems basically for underdeveloped countries. So, Ethiopia is the one among underdeveloped country which characterized by high rate of urban unemployment problem. Debre Birhan town is one among the urban areas of Ethiopia which is affected by the problem of unemployment. Among the causes of unemployment in the town lack of job opportunity, initial capital to start work, lack of skill and experience (lack of education) and rural urban migration are the major ones. In addition to this smoking cigarette and using shisha considered as the cause of unemployment in the town. The consequences of unemployment in the town are dependency, bad ethics and addiction, lack of peace and security and crime.

The study reveals that unemployment is higher in primary school completed and high school completed individuals as they do not graduate from college or university. Most of unemployed individuals are living with their family to satisfy their needs. Unemployment also creates serious problems for the society as the unemployed individuals disturb the whole society, because of these the society have no special attention for them. Due to these they segregate from the society and do not participate in social activities.

In general, unemployment is a serious problem for individuals because it makes people to become poor, and exposed to malnutrition due to lack of income for their living. The unemployment lowers the country GDP as unemployed individual and also do not contribute to the economy.

\subsection{Recommendations}

Based on the findings the followings are recommended.

$\checkmark$ Since, unemployment is one of the problems which exist in Debre Birhan town both governmental and other concerned bodies like Non-governmental organization are responsible to solve these problems like lack of job opportunity, lack of initial capital to start work and lack of skill and experience are the causes of unemployment. So, the government is responsible to reduce these problems by creating conducive environment and allow the expansion of non-governmental organization by creating conducive work environment for them.

$\checkmark$ The expansion of micro and small scale enterprise play an important role to reduce unemployment. So, the government should give special attention such worthy enterprises.

$\checkmark$ The government also responsible to encourage both foreign and domestic investors to invest their 
capital in urban area. When they invest in the form of manufacturing industry or organization it creates job opportunities for unemployed individuals.

$\checkmark$ The government should create conductive environment and providing loan with minimum interest rate for different enterprises.

$\checkmark$ In addition to this, the government should initiate individuals to create new job by themselves and giving rewards for those who become productive. This way best reduce the problem.

\section{References}

(MoFED), M. o. (2010). FederDemocratic Republic of Ethiopia Growth and Transformation Plan 2010/112014/15 . Ethiopian Government Ministry of Finance and Economic Development Press.

Authority), C. (. (2019). Statistical information on the population of Debre Birhan town. Debre Birhan branch.

CSA. (1999). Labour Force Survey. Addis Ababa, Ethiopia .

Dechasa, F. (2014). Unemployment and Labor Market in Urban Ethiopia: Trends and Current Conditions. Sociology and Anthropology journal (2(6)), 207-218.

Gupta, G. (2008). Macro economics theory. New Delhi ,India: Mc Graw- Hill publishing company.

Jeffrey, C. (2010). Geographies of Children and Youth: Eroding Map of Life. Progress in Human Geography (34(4)), 496-505.

Kibru, M. (2012). Employment Challenges in Ethiopia. Addis Ababa: Addis Ababa University press.

kuris, A. (2006). The Ethiopian second Economy (edition ed.). Addis Ababa, Ethiopia: commercial printing enterprise.

Legesse, T. (2015). Challenges and opportunities of youth unemployment: the case of Burayu town. Master's thesis . . Addis Ababa university, Addis Ababa.

Nebil Kellow, Gezahegn Ayele and Hayat Yusu. (2010). Enabling the Private Sector to Contribute to the Reduction of Urban Youth Unemployment in Ethiopia. Addis Ababa chamber of comerce and sectoral association. 